\title{
Cellular/Dendritic Array Tip Morphology During Directional Solidification of Pb-5.8 Wt Pct Sb Alloy
}

Eołew this and additional works at: https://engagedscholarship.csuohio.edu/encbe_facpub

keland State University

t.l.w. DPfors access to this work benefit you? Let us know!

Penslistheta'stimesiment

Copyright 1999 ASM International. This paper was published in Metallurgical and Materials

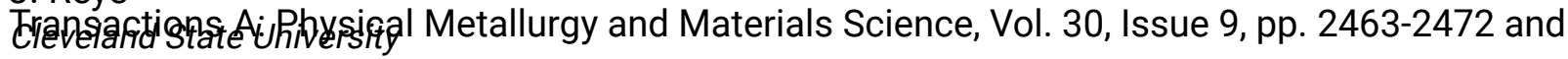
is made available as an electronic reprint with the permission of ASM International. One print or S.ectroihl c copy may be made for personal use only. Systematic or multiple reproduction, Banaras Hindu University

distribution to multiple locations via electronic or other means, duplications of any material in

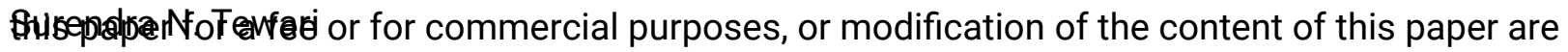
Glokibited. State University

Available on publisher's site at: http://www.asminternational.org/portal/site/www/AsmStore/

ProductDetails/?vgnextoid=813ac777b3426210VgnVCM100000621e010aRCRD.

\section{Original Citation}

Yu, L., Ding, G.L., Reye, J., Ojha, S.N., \& Tewari, S.N. (1999). Cellular/Dendritic Array Tip Morphology During Directional Solidification of Pb-5.8 Wt Pct Sb Alloy. Metallurgical and Materials Transactions A: Physical Metallurgy and Materials Science 30, 2463-2472.

\section{Repository Citation}

Yu, L.; Ding, G. L.; Reye, J.; Ojha, S. N.; and Tewari, Surendra N., "Cellular/Dendritic Array Tip Morphology During Directional Solidification of Pb-5.8 Wt Pct Sb Alloy" (1999). Chemical \& Biomedical Engineering Faculty

Publications. 8.

https://engagedscholarship.csuohio.edu/encbe_facpub/8

This Article is brought to you for free and open access by the Chemical \& Biomedical Engineering Department at EngagedScholarship@CSU. It has been accepted for inclusion in Chemical \& Biomedical Engineering Faculty Publications by an authorized administrator of EngagedScholarship@CSU. For more information, please contact library.es@csuohio.edu. 


\title{
Cellular/Dendritic Array Tip Morphology during Directional Solidification of Pb-5.8 Wt Pct Sb Alloy
}

\author{
L. YU, G.L. DING, J. REYE, S.N. OJHA, and S.N. TEWARI
}

Cellular/dendritic array tip morphology has been examined in directionally solidified and quenched $\mathrm{Pb}-5.8$ wt pct $\mathrm{Sb}$ alloy by a serial sectioning and three-dimensional image reconstruction technique. There is a large scatter in the tip radius, the nearest neighbor spacing, and the mushy zone length, even among the immediately neighboring cells and dendrites. This scatter may be caused by the natural convection (in the mushy zone and in the bulk melt at the array tip), which also produces macrosegregation along the length of the directionally solidified samples. Even in the presence of convection, however, the tip radii are observed to be approximately proportional to the square of the primary spacings, and the radii are in a good quantitative agreement with the predictions from the model due to Hunt-Lu.

\section{INTRODUCTION}

IT is important to understand the development of dendritic microstructures during directional solidification, because these microstructures ultimately control the mechanical properties of directionally solidified components. The cellular/dendritic arrayed growth models ${ }^{[1,2,3]}$ have generally assumed that for a given processing condition, i.e., thermal gradient $\left(G_{l}\right)$, growth speed $(V)$, and solute content of a binary alloy melt $\left(C_{0}\right)$, the array attains a unique morphology, i.e., unique cell/dendrite tip radius and primary spacing. However, experiments, both on transparent alloys ${ }^{[4]}$ and metallic alloys ${ }^{[5,6,7]}$ have shown that a range of primary spacings is stable under a given growth condition. Recent theoretical analyses ${ }^{[8,9,10]}$ also support this view. This would suggest that a range of tip radii may also exist during the steady-state growth of a cellular/dendritic array. The purpose of this research was to investigate this possibility and obtain a quantitative relationship between the primary spacings and the corresponding tip radii during directional solidification of binary metallic alloys.

Three-dimensional arrayed growth during directional solidification of binary alloys with the melt on top and the solid at the bottom can be carried out under two conditions: solutally stable (for example, hypoeutectic $\mathrm{Al}-\mathrm{Cu}$ alloy) and solutally unstable (for example, hypoeutectic $\mathrm{Pb}-\mathrm{Sn}$ ). One would expect that there would be no density inversion in the mushy zone and in the bulk melt ahead of the array tips during directional solidification of hypoeutectic $\mathrm{Al}-\mathrm{Cu}$ alloys, because copper enrichment increases melt density. However, extensive deformation of the cellular/dendritic array tips, attributed to natural convection, has been reported under such growth conditions, ${ }^{[11]}$ which makes it impossible to extract meaningful and accurate tip radii from these experiments. The solutally unstable growth conditions, typified

L. YU, Graduate Student, G.L. DING, Research Associate, J. REYE, Undergraduate Student, and S.N. TEWARI, Professor, are with the Chemical Engineering Department, Cleveland State University, Cleveland, OH 44115. S.N. OJHA, formerly Visiting Professor, Chemical Engineering Department, Cleveland State University, is Professor, Metallurgical Engineering Department, Banaras Hindu University, Varanasi, India.

Manuscript submitted November 19, 1998. by hypoeutectic $\mathrm{Pb}$-Sn alloys, do cause extensive convection, but they also produce cellular and dendritic arrays with uniform morphology if the formation of "channel segregation" can be avoided. ${ }^{[5]}$ This would allow simultaneous measurements of tip radius and primary spacing for the individual cells and dendrites in the array. Therefore, for this study, we selected $\mathrm{Pb}-5.8$ wt pct $\mathrm{Sb}$ alloy, which has a solidification behavior similar to hypoeutectic $\mathrm{Pb}-\mathrm{Sn}$. The metallic alloys are opaque; hence, the tip radii and the corresponding primary arm spacings were determined by metallographic examination of the quenched mushy zone near the tip of cellular/dendritic array.

\section{EXPERIMENTAL PROCEDURE}

\section{A. Alloy Preparation and Directional Solidification}

About 24- to 30-cm-long $\mathrm{Pb}-\mathrm{Sb}$ feed-stock samples were obtained by induction melting a charge $(\mathrm{Pb} 99.99$ wt pct purity and Sb $99.999 \mathrm{wt} / \mathrm{pct}$ purity) under an argon atmosphere in a graphite crucible and pushing the melt into evacuated quartz tubes $(0.6-\mathrm{cm}$ inner diameter (i.d.)) with the help of argon pressure. The cast $\mathrm{Pb}-5.8 \mathrm{wt} / \mathrm{pct} \mathrm{Sb}$ feed-stock cylinders were extracted and placed into the quartz directional solidification ampoule (0.7-cm i.d., 61-cm long). The quartz ampoule was then sealed at the bottom. It was evacuated from the top and heated in the directional solidification furnace to create a $15-$ to $20-\mathrm{cm}$-long melt column. Directional solidification was carried out by withdrawing the ampoule from the furnace assembly at various speeds. After 6 to $10 \mathrm{~cm}$ of directional solidification, the ampoule was quickly pulled from the furnace, and the melt column was quenched by spraying water on the ampoule surface.

Temperature profiles during directional solidification were measured by two chromel-alumel thermocouples (0.01$\mathrm{cm}$ diameter wires kept in closed-end silica capillaries, 0.06$\mathrm{cm}$ outer diameter (o.d.)) with their tips separated by 3 to $5 \mathrm{~cm}$ along the sample length. The steady-state thermal profile was maintained, as indicated by identical thermal profiles obtained from the two thermocouples. The thermal gradient in the liquid at the liquid-solid interface during these experiments was maintained at $140 \mathrm{~K} \mathrm{~cm}^{-1}$. 


\section{B. Metallography and Macrosegregation}

Longitudinal and transverse microstructures were observed by standard optical metallography techniques using an etchant made up of $5 \mathrm{~mL}$ nitric acid, $5 \mathrm{~mL}$ acetic acid, and $90 \mathrm{~mL}$ glycerin. Two-millimeter-thick slices were cut along the length of the directionally solidified (DS) sample as a function of solidification distance. These samples were chemically analyzed by atomic absorption spectroscopy for their $\mathrm{Sb}$ content.

\section{Serial Sectioning and Three-Dimensional Image Reconstruction}

Serial sectioning and three-dimensional image reconstruction techniques were used to obtain the morphological information about the cell/dendrite tips. The cell/dendrite tip position at the time of quench was first located by examining a longitudinal section through the sample. The sample portion containing the mushy zone was then machined out and mounted in epoxy in order to observe the microstructure on the transverse sections. The sample was located in the mount such that the quenched cell/dendrite tips were about $1 \mathrm{~mm}$ below the mount surface. A reference hole was then drilled on the transverse surface of the specimen. A Leica Ultramiller, ${ }^{[12]}$ which can make serial sections and provide a surface finish suitable for optical metallography, was used to obtain transverse microstructures as a function of distance from the quenched array tips. The milled surface was lightly etched in order to reveal the microstructure and record it electronically. The microstructures were recorded with the help of a TV camera (which was attached to the Ultramiller) without removing the sample from the machining stage. The boundary of the reference hole was drawn on a transparent sheet mounted on the monitor. The sample was translated after each serial sectioning so that the image of the reference hole always aligned with the image drawn on the transparent sheet attached to the monitor. This method assured alignment of the transverse images for the subsequent three-dimensional rendering of the cell/dendrite tip morphology. Typically, a sample was cut at 3- to 5- $\mu \mathrm{m}$ steps for a distance of about $100 \mu \mathrm{m}$ from the array tips. Then it was sectioned at 10 - to $50-\mu \mathrm{m}$ steps for a distance of about $0.3 \mathrm{~mm}$ into the mushy zone.

Cell/dendrite boundary was edge tracked and the $(x, y)$ coordinates were corrected by incorporating the calibrated magnifications. The $(x, y)$ coordinates on various transverse sections and their corresponding distance from the tip were then fed into a three-dimensional rendering software, IRIS Explorer 3.5. ${ }^{[13]}$ A "map" made up of the "ReadXYZData," "LatToGeom," and "Render" modules in IRIS Explorer 3.5 takes the $(x, y, z)$ coordinates and transforms them into a three-dimensional view of any particular cell or dendrite. Several sets of coordinates from different cells or dendrites could be fed into the IRIS Explorer at one time to render the three-dimensional view of the array tips.

\section{RESULTS}

\section{A. Microstructure and Macrosegregation}

Figure 1 shows the temperature profiles recorded by the two thermocouples during a typical experiment. The profiles

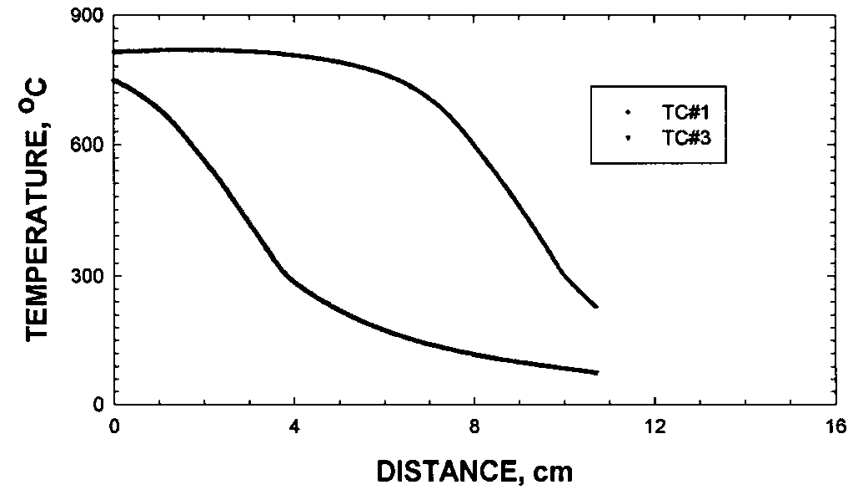

(a)

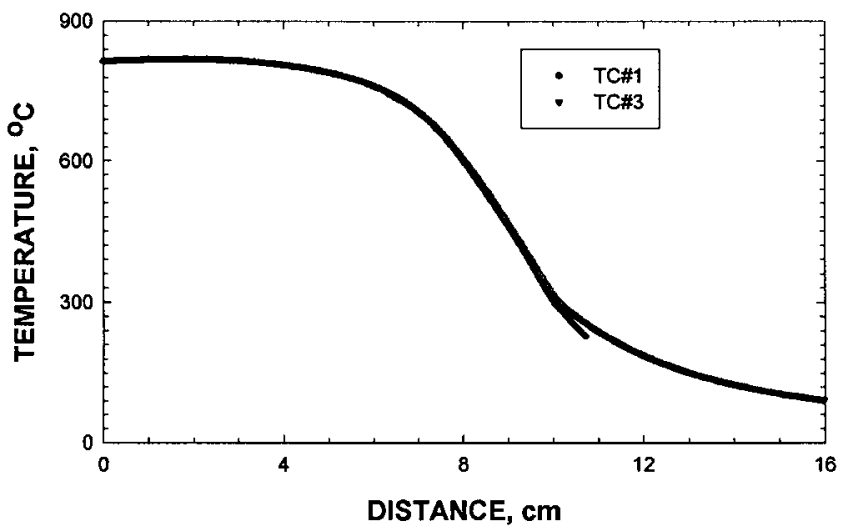

(b)

Fig. 1-Typical thermal profile during directional solidification of $\mathrm{Pb}-5.8$ wt pct Sb alloy. (a) Temperature profiles recorded by two thermocouples spaced $6.3 \mathrm{~cm}$ apart along the sample axis. (b) Steady-state thermal profile during directional solidification is indicated by identical temperature $v s$ distance history as recorded by the two thermocouples.

from the two thermocouples are almost identical, as seen by translating one with respect to the other (Figure 1(b)). This indicates a steady-state thermal field during directional solidification. A thermal gradient of $140 \mathrm{~K} \mathrm{~cm}^{-1}$ in the melt at the cellular/dendritic array tips was used for the samples examined in this study.

Figure 2 shows the typical longitudinal microstructures of cellular and dendritic arrays at their tips in $\mathrm{Pb}-5.8 \mathrm{wt}$ pct $\mathrm{Sb}$ alloy directionally solidified at different growth velocities. It is apparent that the cells and dendrites are aligned nearly parallel to the alloy growth direction. With increasing growth velocity, the morphology changes from cell to dendrite. For this thermal gradient, the cell-to-dendrite transition occurs at $1.5 \mu \mathrm{m} \mathrm{s}^{-1}$.

Typical growth speed dependence of the longitudinal macrosegregation is shown in Figure 3 , which plots $C_{a} / C_{0}$ versus fraction solidified $\left(f_{s},\right)$, where $C_{s}$ is the $\mathrm{Sb}$ content in the solid, $f_{s}$ is fraction distance solidified, and $C_{0}$ is the original antimony content of the melt. In this figure, the symbols marked by "L" correspond to the quenched liquid portion of the specimens. For each directionally solidified specimen, the $C_{0}$ values, obtained by measuring the area under the $C_{s}$ vs $f_{s}$ plots, which included both the directionally solidified and quenched melt portions, was found to be within \pm 5 pct of the analysis done on the precast feed-stock bars. This figure shows that the $C_{s} / C_{0}$ value increases from less than unity to values larger than unity as a function of $f_{s}$. This is 


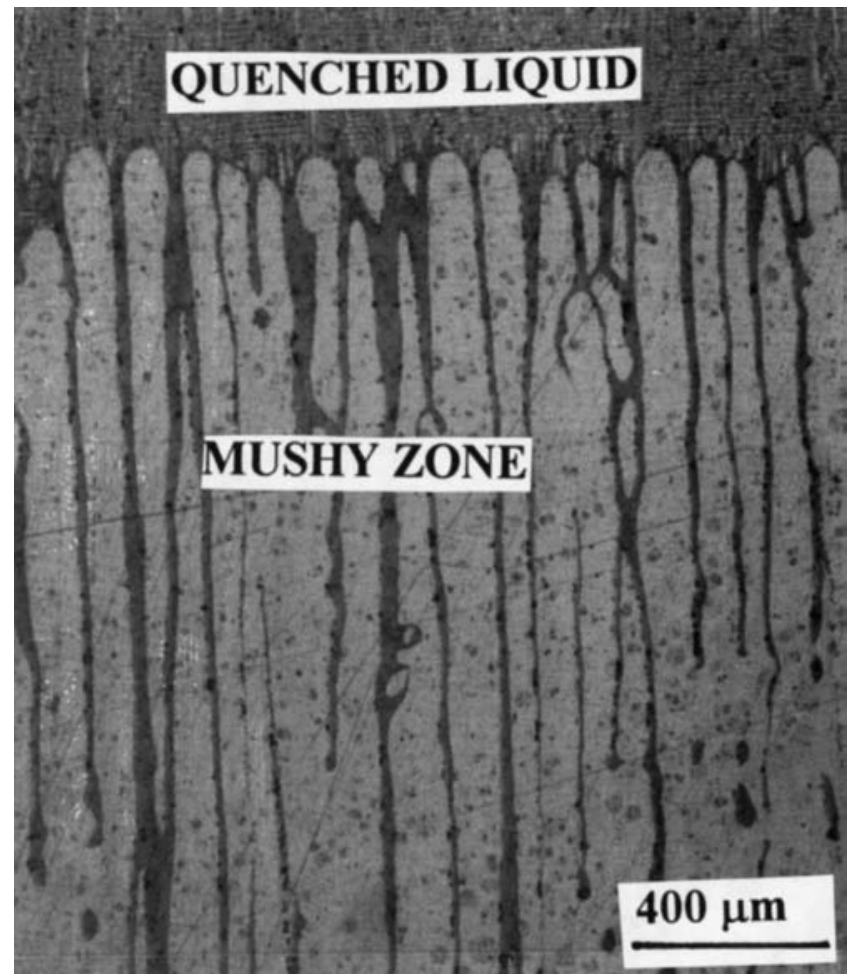

(a)

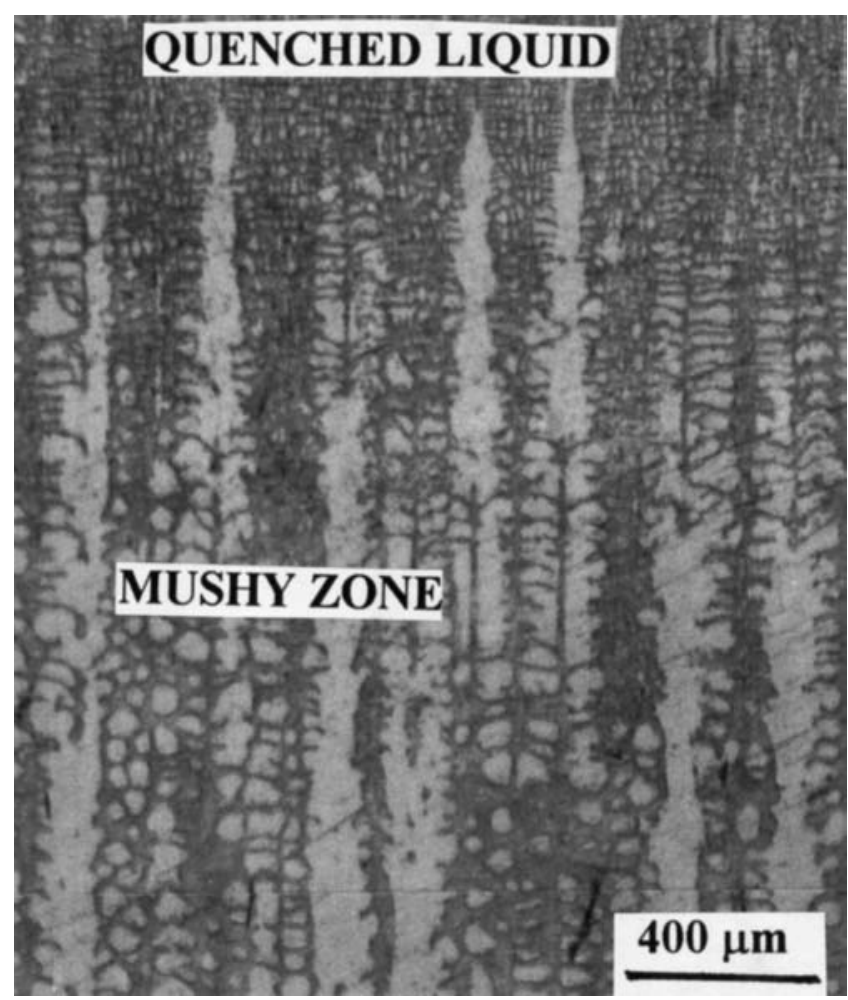

(b)

Fig. 2-Typical longitudinal (parallel to the alloy growth direction) microstructure of $\mathrm{Pb}-5.8 \mathrm{wt}$ pct $\mathrm{Sb}$ directionally solidified at $140 \mathrm{~K} \mathrm{~cm}^{-1}$ : (a) cellular $\left(V=0.8 \mu \mathrm{m} \mathrm{s}^{-1}\right)$; and $(b)$ dendritic $\left(V=3 \mu \mathrm{m} \mathrm{s}^{-1}\right)$.

an indication of extensive mixing between the interdendritic mushy zone liquid and the bulk melt ahead of the cellualar/ dendritic arrays. In the absence of convection, a uniform

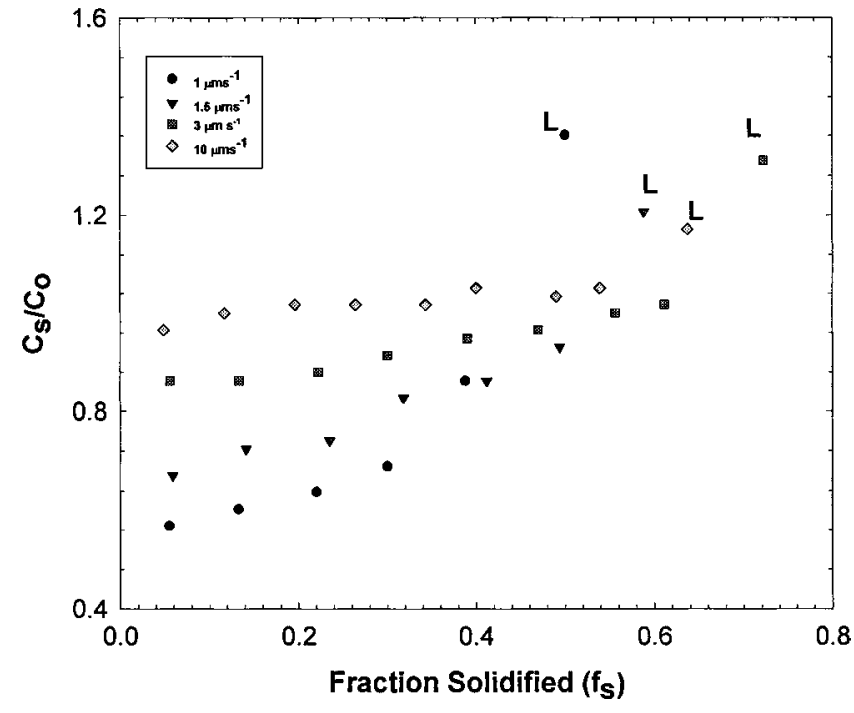

Fig. 3-Influence of growth speed on the macrosegregation along the directionally solidified length of Pb-5.8 wt pct $\mathrm{Sb}\left(G_{l}=140 \mathrm{~K} \mathrm{~cm}^{-1}\right)$.

solute content will be expected along the entire length of directionally solidified specimens (except for the initial and final transients, which would be of about the same size as the mushy zone length). Data for one as-cast feed-stock sample, which was similarly analyzed along the specimen length and did not show longitudinal macrosegregation, have not been included in this figure for the sake of clarity. The extent of macrosegregation increases with decreasing growth velocity. Convection is caused by the density inversion in the interdendritic melt (Sb content increases toward the bottom of the mushy zone and reduces the melt density) and in the bulk melt immediately ahead of the tip because of the solutal buildup. ${ }^{[14]}$ The extent of convective mixing increases with decreasing growth speed.

\section{B. Spatial Uncertainty Caused by the Serial Sectioning and Three-Dimensional Image Reconstruction Technique}

Figure 4 shows typical transverse microstructures observed on serial sections in the mushy zone as a function of distance from the quenched tip for a $\mathrm{Pb}-5.8$ wt pct $\mathrm{Sb}$ alloy sample grown at $3 \mu \mathrm{m} \mathrm{s}^{-1}$. The corresponding distances from the tip are shown below the images. Such transverse images were used to obtain the three-dimensional rendering of the array tips. The crescent on the right side of the images corresponds to the reference hole that was used for vertical alignment of these images. The $X-Y$ uncertainty of the serial sections can be estimated by edge tracking the reference holes from several sections and comparing them with respect to each other. A typical comparison is shown in Figure 4(e), which shows the location of the reference hole on two serial sections. The extent of misalignment is indicated by the $X-Y$ shift between the two contours. The errors in the $X$ and $Y$ directions were observed to be $5 \pm 3$ and $2 \pm 1 \mu \mathrm{m}$, respectively. This error can be significantly improved by using vertical holes of smaller diameter for image alignment.

The random error introduced into the $Z$-axis (vertical distance between the serial sections) is less than $1 \mu \mathrm{m}$. This 


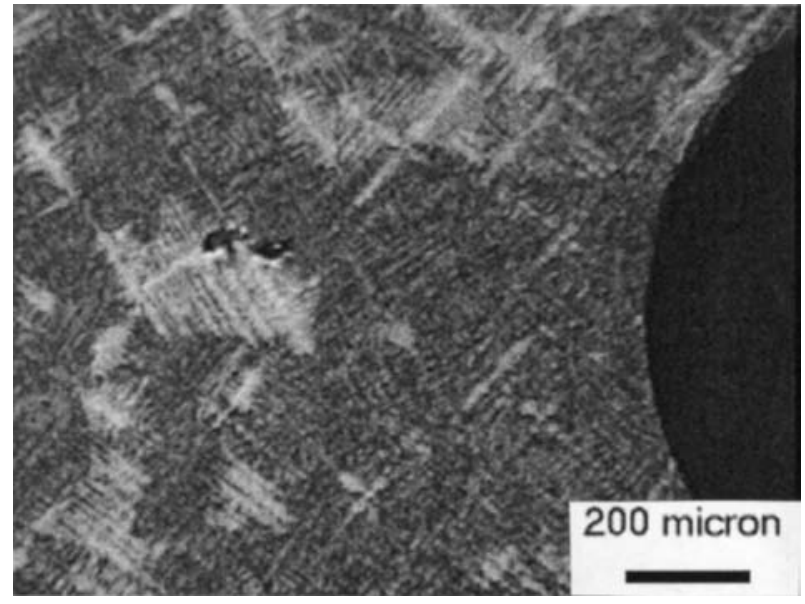

(a)

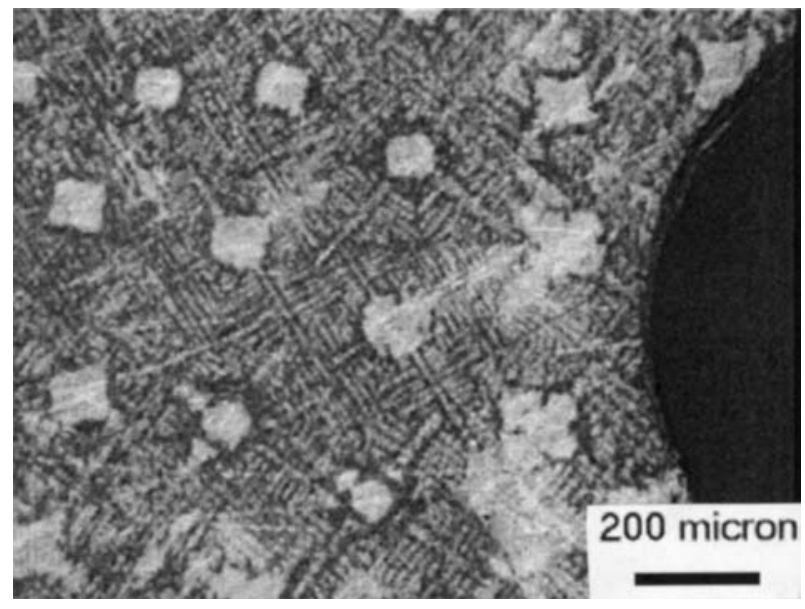

(c)

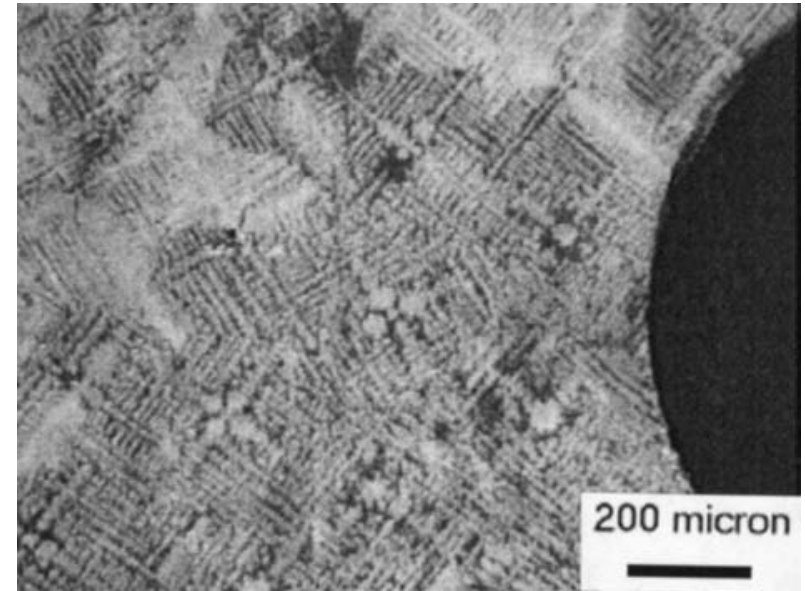

(b)

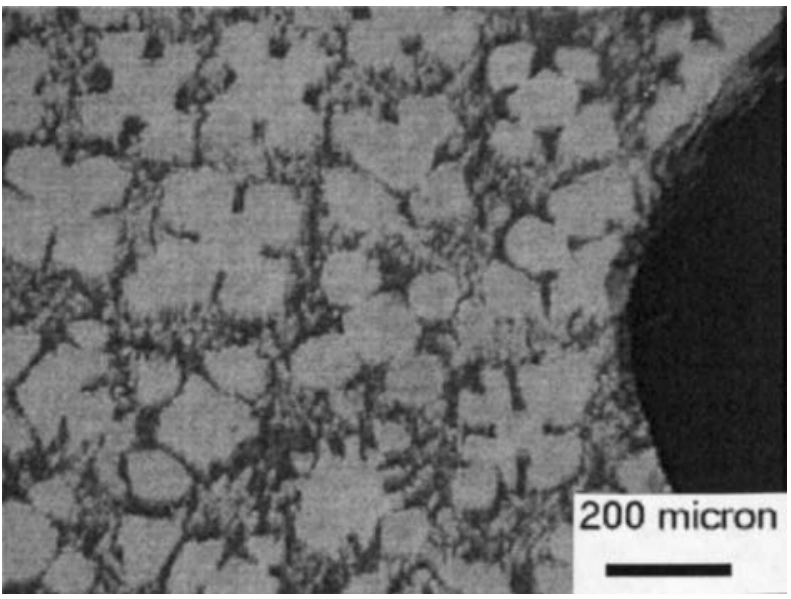

(d)

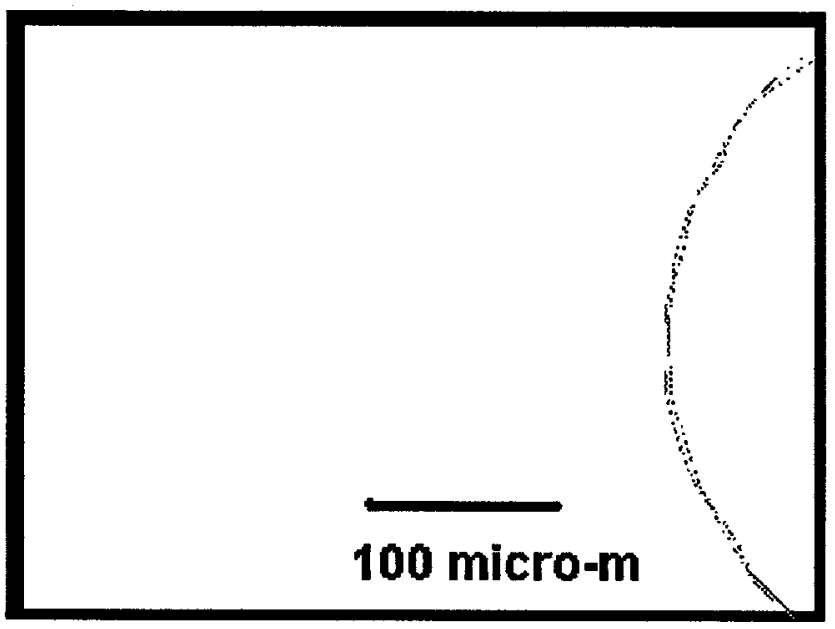

(e)

Fig. 4-Typical microstructures observed on serial sections (transverse) in the mushy zone as a function of distance from the quenched tip: (a) at tip, (b) $32 \mu \mathrm{m}$ from tip, (c) $90 \mu \mathrm{m}$ from tip, (d) $318 \mu \mathrm{m}$ from tip, and (e) difference between two typical reference hole images, which were recorded at 90 and $140 \mu \mathrm{m}$ from tip.

was examined in the following manner. A short length of a $25 \pm 1 \mu \mathrm{m}$ diameter chromel wire was laid horizontally on a flat bed and covered with epoxy. The mounted sample was then sectioned by the Ultramiller at $1 \mu \mathrm{m}$ steps. Figure 5(a) shows typical longitudinal sections through the wire as a function of distance from its cylindrical surface. The image of the machined wire as observed on the serial sections became continually wider until the wire was sectioned almost through its middle. During the subsequent sectioning, the remaining portion of the wire (half the cylinder) pulled 


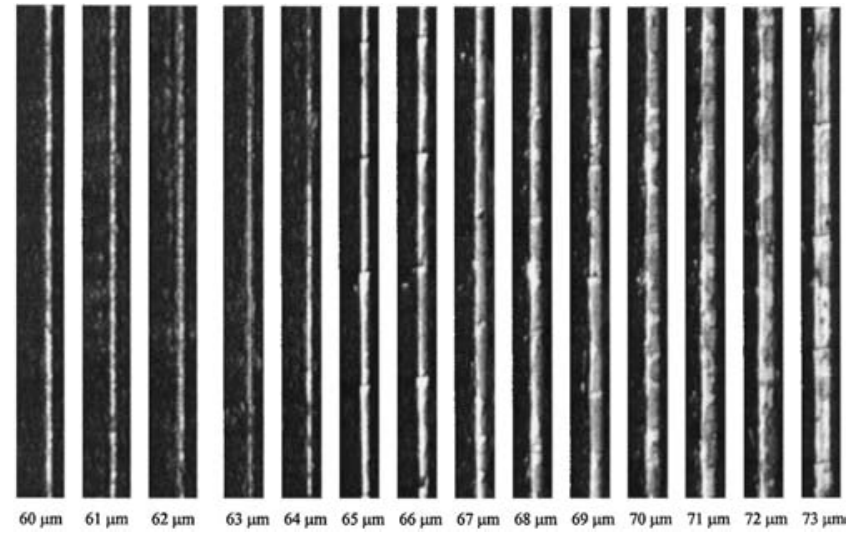

(a)
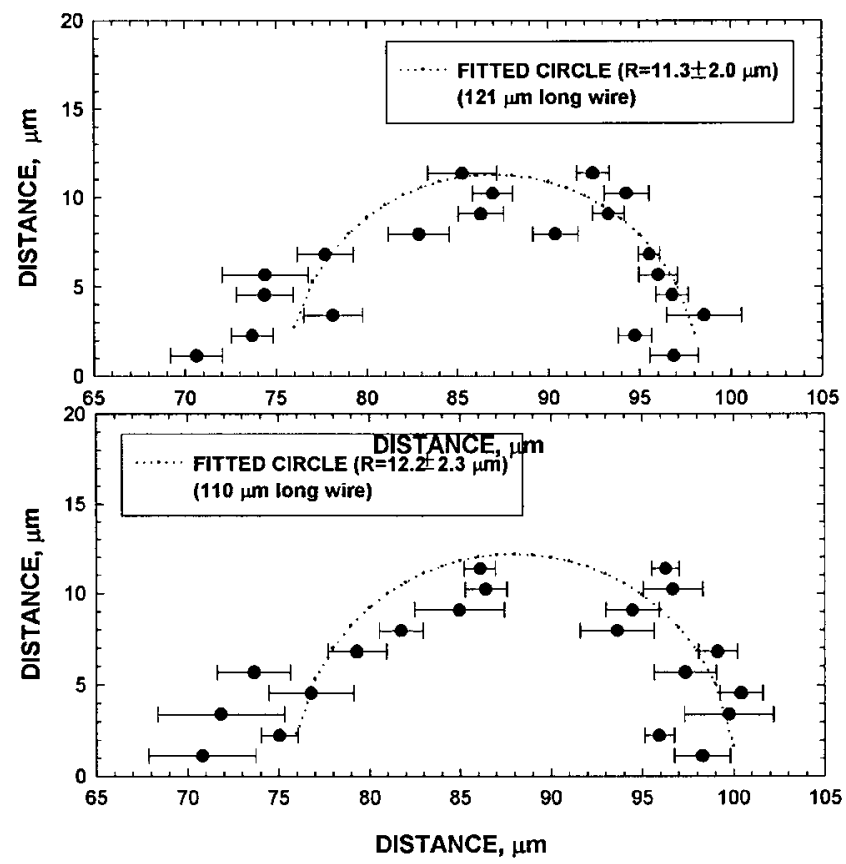

(b)

Fig. 5-Typical spatial uncertainty during Ultramiller serial sectioning and three-dimensional image reconstruction. (a) Longitudinal serial sections through a $25-\mu \mathrm{m}$-diameter wire as a function of distance. The leftmost view is the first cut through the wire, and the rightmost view is the last cut through the wire (before the wire pulled off from the mount). (b) Edgeon view of the three-dimensional reconstructed wire and the half-circle regression fit through the data to obtain the wire radius.

off from the epoxy mount. For several wires, it was observed that 11 to 13 steps of $1-\mu \mathrm{m}$ machining were required before the center of the wire was reached and the wire pulled off from the epoxy. This suggests that the error in the vertical direction (Z-axis) during serial sectioning is less than $1 \mu \mathrm{m}$.

Two longitudinal segments of the wire, 121- and $110-\mu \mathrm{m}$ long, respectively, were used for the edge-on visualization shown in Figure 5(b). The symbols in this figure indicate the mean values of the $X$-coordinates corresponding to the left and right edges of the wire, as seen on the various serial sections. The error bars indicate one standard deviation for the $X$-coordinates as recorded along the entire length of the wire segment. The abscissa in Figure 5(b) indicates the distance from the center of the wire for the various serial sections (the section at which the wire got pulled off was

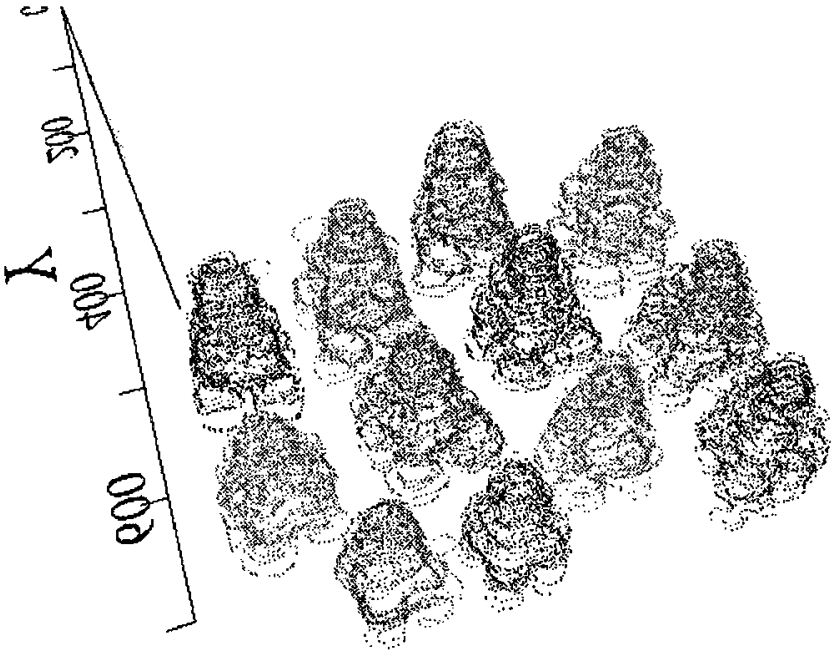

Fig. 6-Three-dimensional view of a typical dendritic array near its tip $\left(G_{l}=140 \mathrm{~K} \mathrm{~cm}^{-1} ; V=3 \mu \mathrm{m} \mathrm{s}^{-1}\right)$.

assumed to correspond to the wire's center). This figure indicates that the typical $X, Y$ translation uncertainties are about 2 to $3 \mu \mathrm{m}$. A half-circle regression fit to the data in Figure 5(b) yielded the radius values for the two wire segments to be $11.3 \pm 2.0$ and $12.2 \pm 2.3 \mu \mathrm{m}$, respectively. These two values are very close to the actual radius of the wire, $12.5 \mu \mathrm{m}$. This indicates that the serial sectioning and three-dimensional image reconstruction technique used in this study is reliable.

\section{Cellular/Dendritic Tip Morphology}

Figure 6 shows a three-dimensional rendering of a dendrite array that was used to measure the dendrite tip radii. One typical dendrite from this array is shown in Figure 7 (bottom right), which shows four two-dimensional views of this dendrite as it is rotated around its axis at $45 \mathrm{deg}$ intervals. Examination of these four views indicates that the dendritic envelope is not axisymmetric. However, these two-dimensional views can be used to measure the dendrite tip radius $\left(R_{t}\right)$ by using a parabolic fit to the data points located on the outer periphery of the dendrites. One can thus obtain four different tip radii corresponding to the four views of the same dendrite, or all four views can be combined together to yield one overall tip radius for this dendrite. Figure 8 shows the four two-dimensional views of this dendrite (thin lines) and an overall parabolic fit (thick curve) through all the data points. The overall mean tip radius for this dendrite is $14.2 \mu \mathrm{m}$.

Even though the dendrites present in the cluster (Figure 6) were growing at the same growth speed and under an identical thermal gradient, their nearest neighbor spacing distribution was not uniform, as seen from the transverse view of the dendrites (Figure 9). For each dendrite whose tip radius was determined, we also measured its mean nearest neighbor spacing (primary dendrite spacing). Figure 9 plots the experimentally measured dendrite tip radius $v s$ the corresponding primary dendrite spacing. The small symbols correspond to the tip radius obtained from the four views of the individual dendrite, and the thick symbol corresponds to its overall mean tip radius. The tip radius within this dendrite 

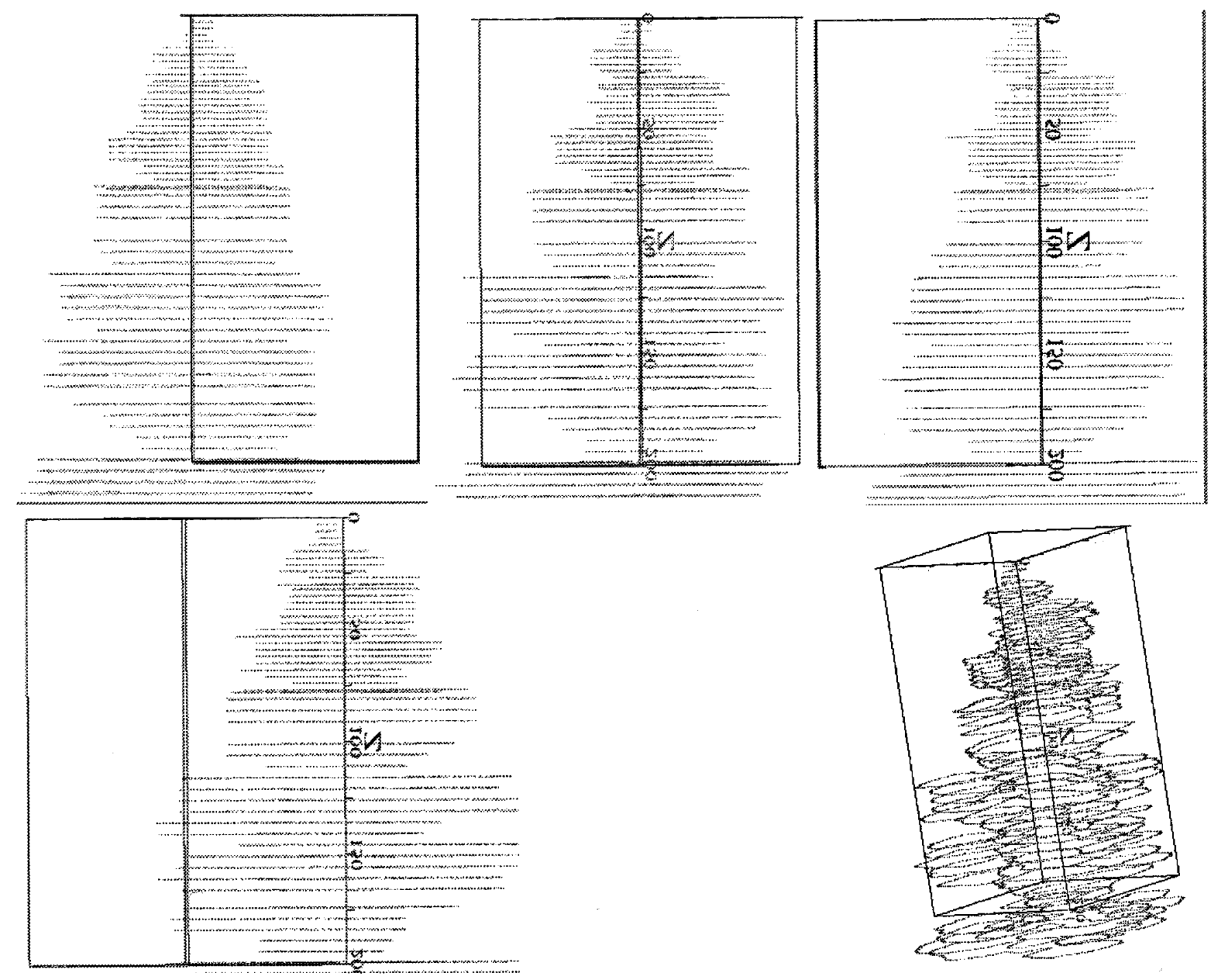

Fig. 7-Four typical views of a dendrite tip as the dendrite is rotated at 45 deg steps about its axis. The image at the bottom right is the three-dimension al representation of this dendrite.

cluster varies from 12 to $28 \mu \mathrm{m}$ and the primary dendrite spacing in the same cluster varies from 160 to $203 \mu \mathrm{m}$, even though all these dendrites were presumably growing under identical conditions. Despite all this scatter, there is a clear indication that dendrites whose immediate neighbors are located farther apart tend to have larger tip radii. Combining all the tip radii data together, the overall tip radius for this sample turns out to be $19.8 \pm 5.1 \mu \mathrm{m}$.

Similar behavior was also observed for the cellular arrays, as shown in Figure 10. The micrograph in this figure shows the cell cluster from which the individual cell tip radii were determined. The three-dimensional views for the cells were constructed in a manner identical to the dendrites. Since their tips were also not axisymmetric, the tip radius was determined from the four views of a cell, as described previously for the dendrites (rotating the individual cells along their axis at 45-deg steps). The shape near the tip was not parabolic; it was closer to circular. Therefore, the radius was determined by fitting semicircles to the four views of the tip. Dependence of these tip radii on their nearest neighbor spacing is presented in Figure 10. The cells have a much larger scatter in their tip radius as compared with the dendrites. The overall tip radius for this cellular sample, grown at $1 \mu \mathrm{m} \mathrm{s}^{-1}$, is $49 \pm 23 \mu \mathrm{m}$ as compared with $19.8 \pm 5.1$ $\mu \mathrm{m}$ for the dendritic sample grown at $3 \mu \mathrm{m} \mathrm{s}^{-1}$. The large scatter can be attributed to the nonuniformity of the cell distribution on the transverse section, as seen in the micrograph (Figure 10), and anisotropy in the tip shape. For example, the cell number 22 has six immediate neighbors and is axisymmetric, where as, cell number 14 has seven immediate neighbors and is highly asymmetric. The tendency for the cell tip radius to increase with the increasing nearest neighbor spacing is not as evident as it was for the dendrites.

A closer examination of the transverse microstructures of the cellular and dendritic arrays near their tip (Figure 11) shows that the cells (and dendrites) do not have a uniform mushy zone length. Some of them lead their immediate neighbors, and some lag behind. The dendrite marked by an arrow in Figure 11(a) at $61 \mu \mathrm{m}$ from the interface did not even show up in the cross-sectional view at $46 \mu \mathrm{m}$ from the interface. Similarly, the cell marked by an arrow in Figure 11(b) at $75 \mu \mathrm{m}$ from the interface did not show up in the 


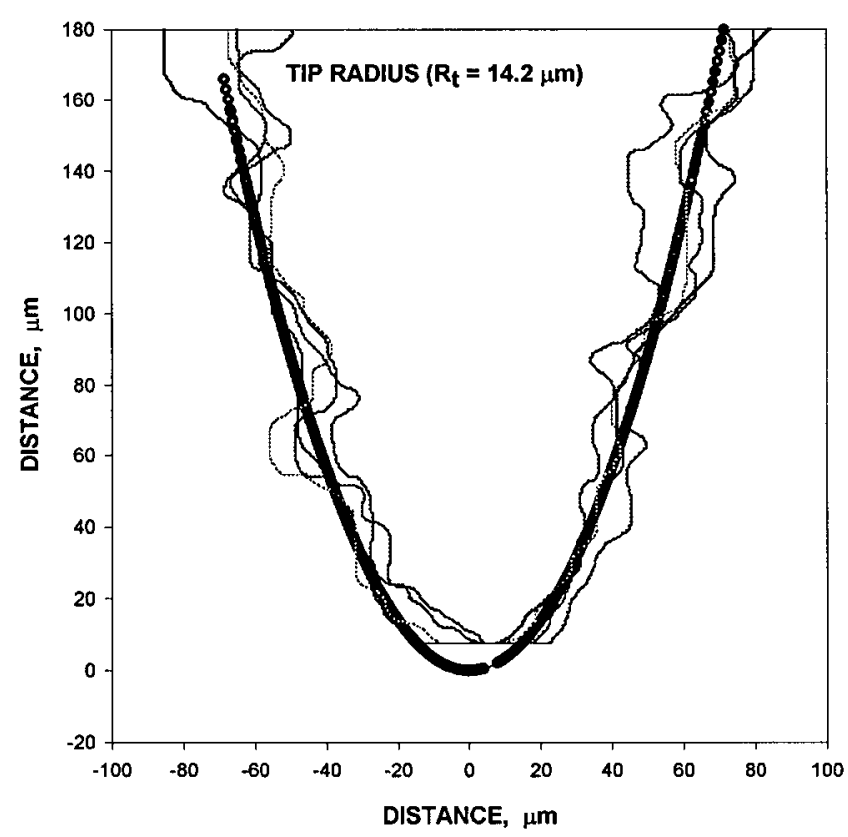

Fig. 8-Four views of a dendrite tip fitted with a parabolic function to obtain the tip radius.

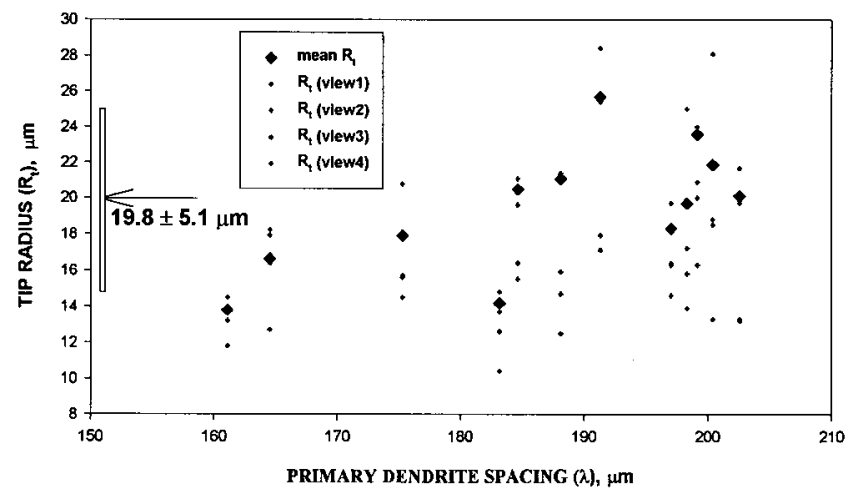

(a)

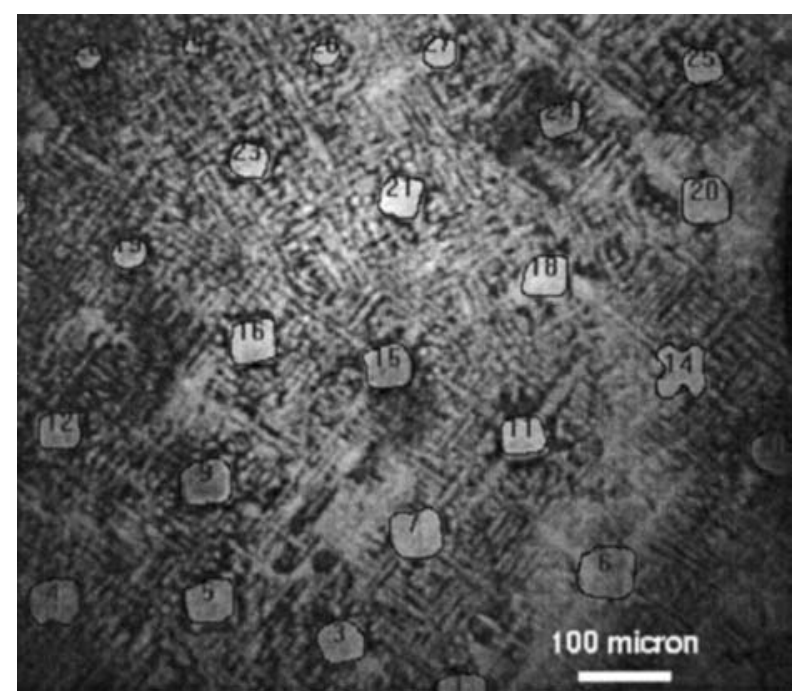

(b)

Fig. 9-Tip radius and primary dendrite spacing variation among neighboring dendrites $\left(G_{2}=140 \mathrm{~K} \mathrm{~cm}^{-1} ; V=3 \mu \mathrm{m} \mathrm{s}^{-1}\right)$.

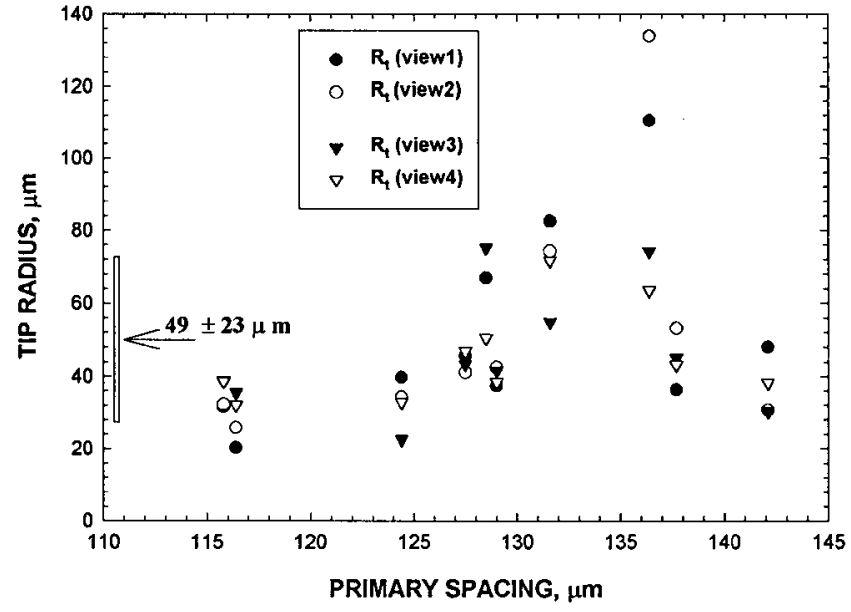

(a)

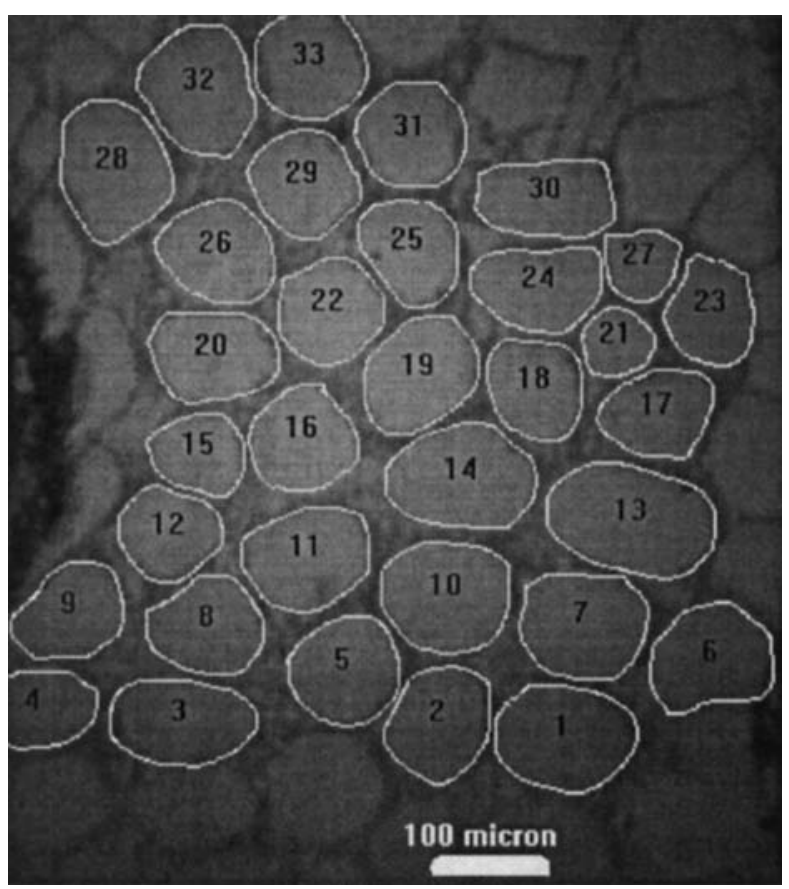

(b)

Fig. 10-Tip radius and primary spacing variation among neighboring cells $\left(G_{l}=140 \mathrm{~K} \mathrm{~cm}^{-1} ; V=1 \mu \mathrm{m} \mathrm{s}^{-1}\right)$.

cross-sectional view at $45 \mu \mathrm{m}$ from the interface. Under diffusive thermal and mass transport conditions, one would expect that the leading cells or dendrites would have a smaller tip radius as compared with their lagging neighbors. However, when we plotted the tip radius as a function of distance from the tip of the leading cell (or dendrite), no such correlation was found. Figure 11 also reinforces the previously made observation that axial asymmetry at the tip is considerably more for cells than for dendrites.

\section{Growth Speed Dependence of Cell/Dendrite Tip Radius}

Figure 12 shows the growth speed dependence of the cell/dendrite tip radius for the $\mathrm{Pb}-5.8 \mathrm{wt}$ pct $\mathrm{Sb}$ samples directionally solidified at $140 \mathrm{~K} \mathrm{~cm}^{-1}$. The morphology is 


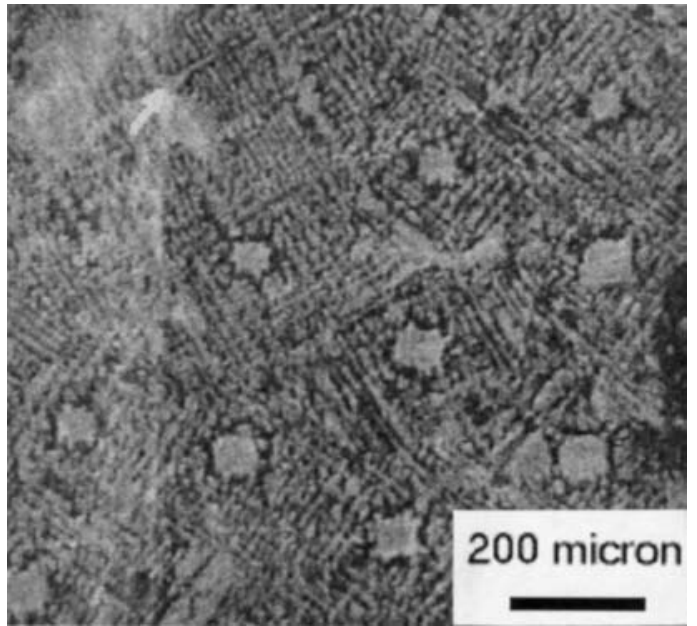

(a)

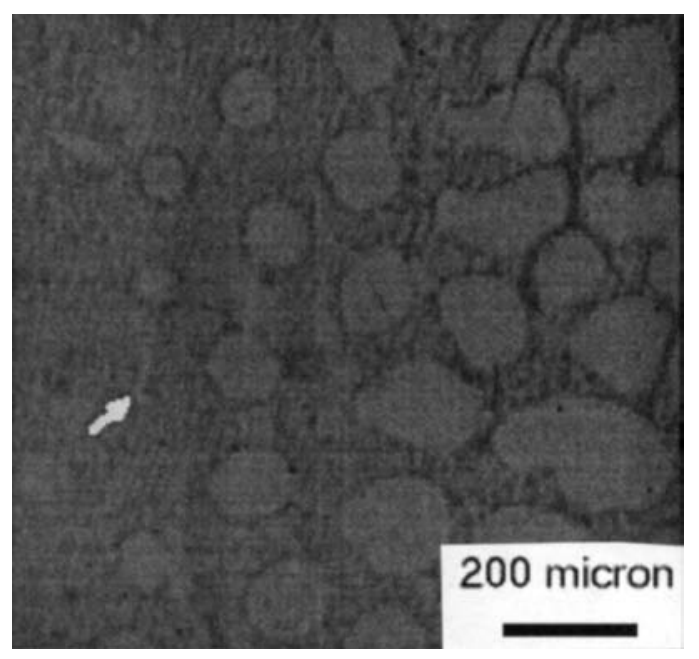

$(c)$

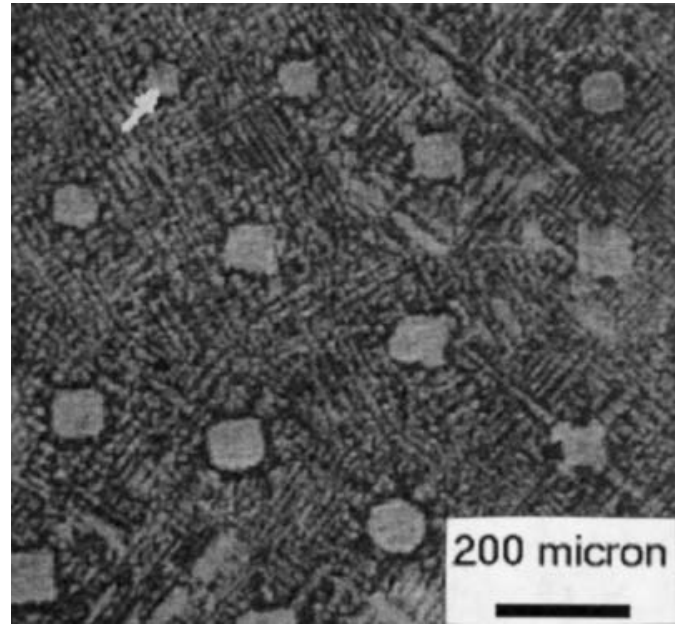

(b)

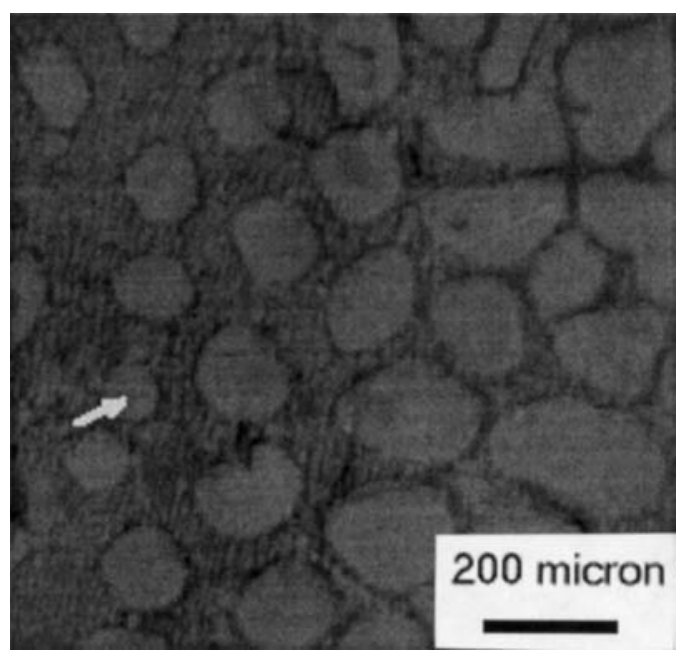

$(d)$

Fig. 11-Some of the cells and dendrites lead their immediate neighbors in the array. ( $a \& b$ ) Transverse sections through the dendritic array at 46 and 61 $\mu \mathrm{m}$ from the interface. $(c \& d)$ Transverse sections through the cellular array at 45 and $75 \mu \mathrm{m}$ from the interface.

GROWTH SPEED DEPENDENCE OF CELL/DENDRITE TIP RADII $\left(\mathrm{Pb}-5.8 \mathrm{wt} \% \mathrm{Sb}, 140 \mathrm{~K} \mathrm{~cm}^{-1}\right.$ )

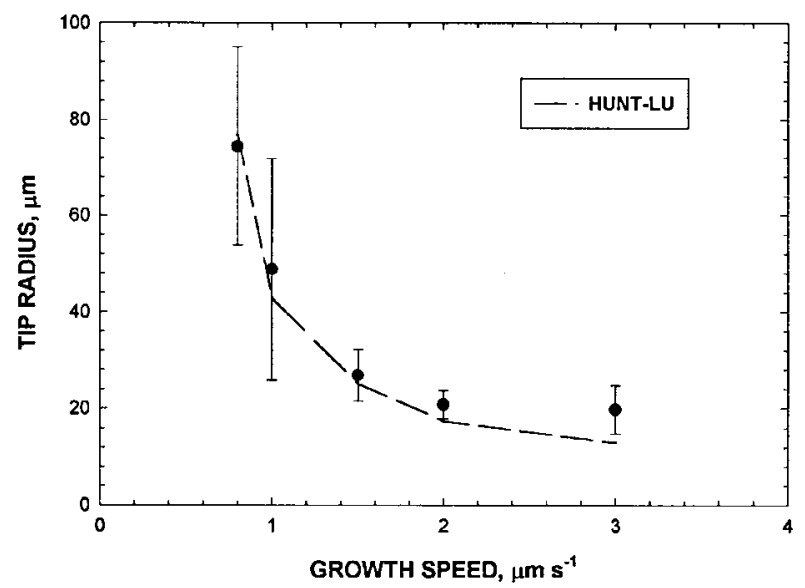

Fig. 12-Growth speed dependence of cell/dendrite tip radii $\left(R_{t}\right)$. cellular at growth speeds below $1.5 \mu \mathrm{m} \mathrm{s}^{-1}$. It is dendritic at higher speeds. There is a larger scatter in the experimentally determined tip radius for the cells as compared with the dendrites. The tip radius decreases with increasing growth speed.

\section{DISCUSSION}

Hunt- $\mathrm{Lu}^{[8]}$ provide the following expressions for the cell and dendrite tip radius $R_{t}$ during directional solidification of binary alloys.

For cells: $R_{t}=2 \Gamma /\left(\Delta T_{\sigma}^{\prime}, \Delta T_{0}\right)$,

$$
\begin{aligned}
& \text { where } \Delta T_{\sigma}^{\prime}=a\left(V^{\prime}-G^{\prime}\right)^{0.55}\left(1-V^{\prime}\right)^{1.5} \text { and } \\
& \begin{array}{l}
a=0.5582-0.2267 \log _{10}(k) \\
+0.2034\left[\log _{10}(k)\right]^{2}
\end{array}
\end{aligned}
$$

For dendrites: $R_{t}=2 \Gamma /\left(\Delta T_{\sigma}^{\prime} \Delta T_{0}\right)$,

$$
\text { where } \Delta T_{\sigma}^{\prime}=0.41\left(V^{\prime}-G^{\prime}\right)^{0.55}
$$



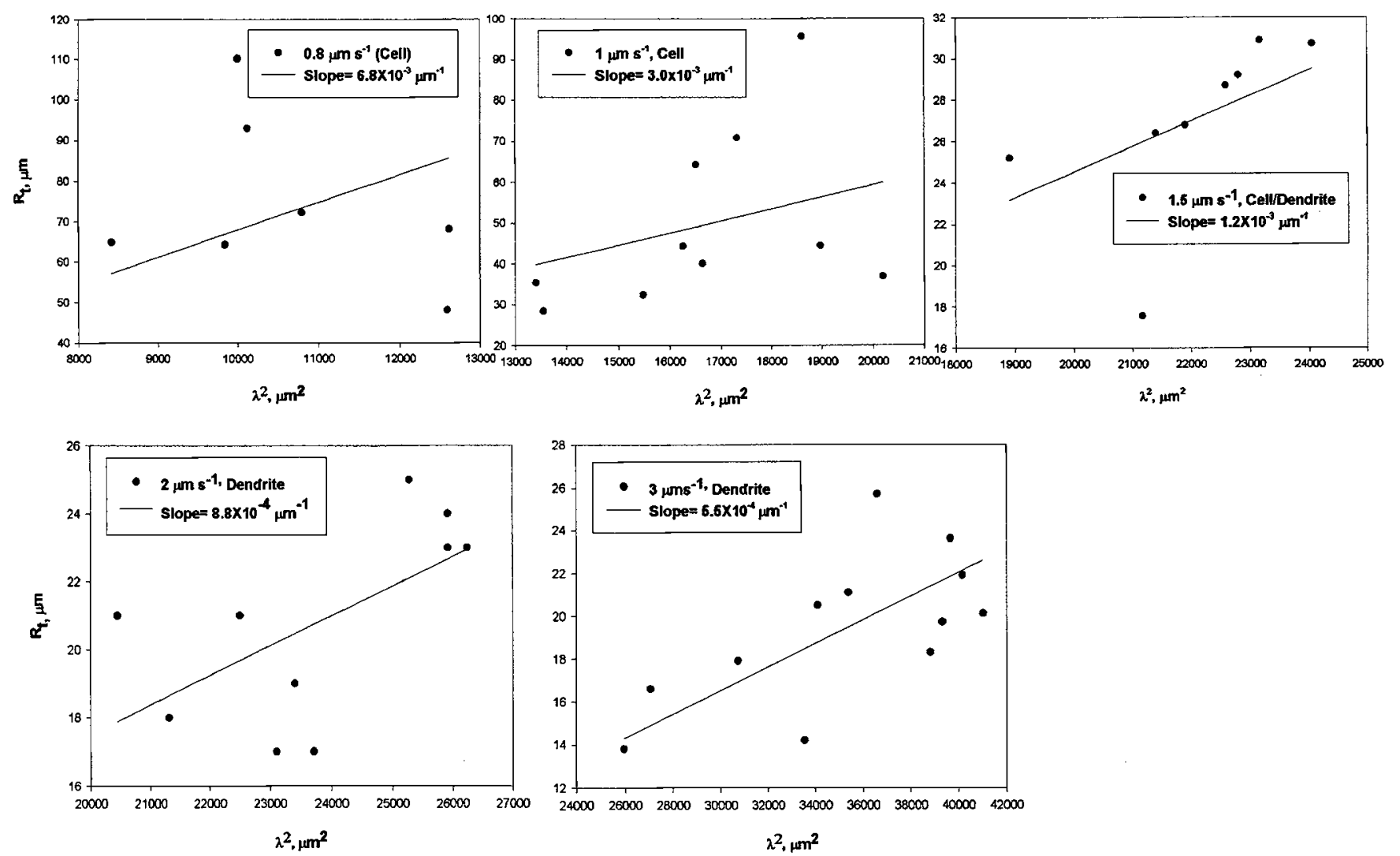

Fig. 13- $R_{t} v s$ nearest neighbor spacing, $\lambda^{2}$, for Pb-5.8 wt pct $\mathrm{Sb}$ alloy directionally solidified at $140 \mathrm{~K} \mathrm{~cm}^{-1}$. The $R_{t}$ values are the mean from the four views of the individual cell/dendrite. Corresponding growth speeds and morphology are indicated in the figure. Solid lines are the linear regression (forced to pass through origin) through the data, and the corresponding slope values are indicated in the figure.

Here, $G^{\prime}=G_{l} \Gamma k / \Delta T_{0}^{2}$, and $V^{\prime}=V \Gamma k /\left(D \Delta T_{0}\right)$. The term $G_{l}$ is thermal gradient, $k$ the solute partition coefficient, $\Gamma$ the capillarity constant, $D$ the solute diffusion coefficient in the melt, and $\Delta T_{0}$ the alloy freezing range. We use the following values for the various parameters: $G_{l}=140 \mathrm{~K} \mathrm{~cm}^{-1}$. $C_{0}=$ 5.8 wt pet $\mathrm{Sb}, k=0.4^{[15]}, m_{l}=6.8 \mathrm{~K}$ wt pet $\mathrm{Sb}^{[15]} \Gamma=$ $0.089 \mu \mathrm{m} \mathrm{K},{ }^{[16]}$ and $D_{l}=3 \times 10^{-5} \mathrm{~cm}^{2} \mathrm{~s}^{-1[17]}$ in order to calculate the predicted tip radii for the cell and dendrite morphologies (cells for growth speed of $1.5 \mu \mathrm{m} \mathrm{s}^{-1}$ and below; and dendrite for higher speed). The prediction is shown in Figure 12 as a broken line. It is interesting to note that, despite the presence of significant convection during these experiments, as evidenced by the extensive longitudinal macrosegregation, there is good agreement between the experimentally observed and theoretically predicted tip radii.

Hunt ${ }^{[18]}$ proposed the following analytical relationship to predict the primary arm spacings $(\lambda): \lambda^{2}=4 \sqrt{2}\left[\left(G_{c}^{t}-G_{c}\right)\right.$ $-1]\left(D_{l} / V\right) R_{t}$, where $G_{c}^{t}$ is the solutal gradient ahead of the cell/dendrite tip and $G_{c}$ is the solutal gradient in the interdendritic melt. This approach assumes that the primary spacing is determined by the tip radius of the dendrite. It suggests that, for a given growth condition, $R_{t}$ would be proportional to $\lambda^{2}$. Other investigators have incorporated tip radius predictions based on their own model into this relationship in order to predict the primary spacings. ${ }^{[3,19]}$ These models have generally assumed that the tip radius of the array is selected by the liquid-solid surface energy. Spencer and Huppert ${ }^{[10]}$ recently carried out an analysis showing that the tip radius of the dendrite is selected by the array spacing and not by the surface energy. This analysis also suggests that $R_{t}$ would be approximately proportional to $\lambda^{2}$.

Figure 13 plots the experimentally observed $R_{t} v s \lambda^{2}$ for all the samples examined in the present study. The data points represent the mean of the four tip radii from the four views for each cell or dendrite. The solid lines are the linear regression through the data (while forcing the lines to pass through the origin). The $R_{t} v s \lambda^{2}$ slopes thus obtained are indicated in these figures. The slope appears to decrease with increasing growth speed.

In order to obtain the theoretical predictions of the $R_{t} v s$ $\lambda^{2}$ slope, the following $G_{c}^{t} v s$ growth parameter relationships for cells and dendrites ${ }^{[8]}$ were incorporated in the $\lambda^{2} v s R_{t}^{[18]}$ expression presented previously. The solutal gradient ahead of the tips $\left(G_{c}^{t}\right)$ is $-V C_{t}(1-k) / D$, and that in the interdendritic melt $\left(G_{c}\right)$ is $G_{l} / m_{l}$. Hunt-Lu ${ }^{[8]}$ give the following relationships to predict the tip composition $\left(C_{t}\right)$ for cells and dendrites, $C_{t}=C_{0}+\Delta T_{s}^{\prime} \Delta T_{0} / m$. For cells:

$$
\Delta T_{s}^{\prime}=\frac{G^{\prime}}{V^{\prime}}+a+(1-a) V^{\prime 0.45}-\frac{G^{\prime}}{V^{\prime}}\left(a+(1-a)^{0.45}\right)
$$

where

$$
a=5.273 \times 10^{-3}+0.5519 k-0.1865 k^{2} .
$$

For dendrites:

$$
\Delta T_{S}^{\prime}=\left(\frac{G^{\prime}}{V^{\prime}}\right)^{c}+a V^{\prime b}+(1-a) V^{\prime 1.2 b}
$$




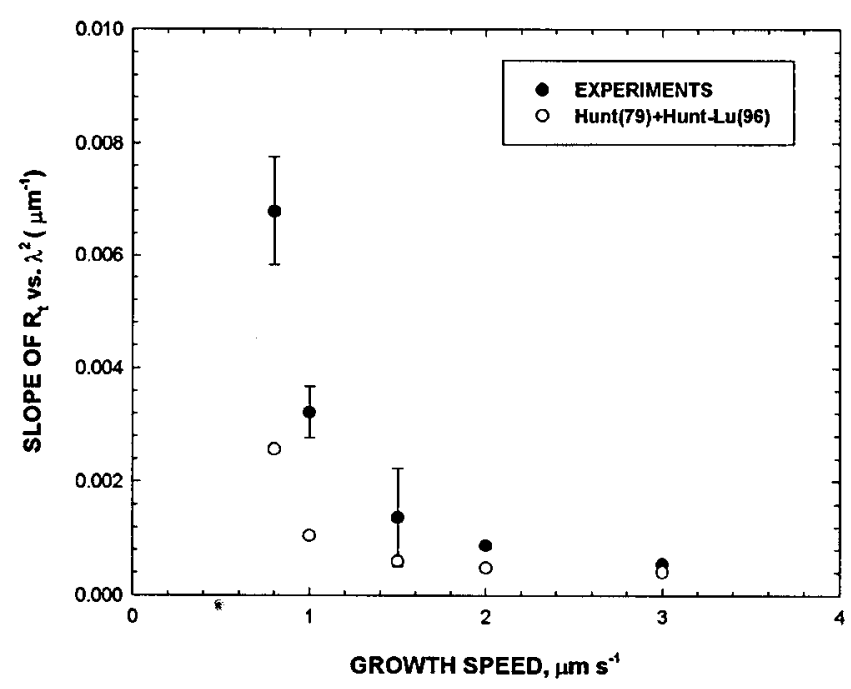

Fig. 14-Slope of $R_{t} v s \lambda^{2}$ plots $v s$ the alloy growth speed. Filled symbols indicate the experimentally determined values of the slope, and the open symbols are the theoretical predictions.

where

$$
\begin{aligned}
a= & 8.734+5.930 \log _{10}(k)+0.2578\left[\log _{10}(k)\right]^{2} \\
b= & 0.4307-0.1656 \times 10^{-3} \log _{10}(k)-0.04455 \\
& {\left[\log _{10}(k)\right]^{2} }
\end{aligned}
$$

and

$$
\begin{aligned}
c= & 1.454+0.2735 \log _{10}\left(G^{\prime}\right)+0.04145\left[\log _{10}\left(G^{\prime}\right)\right]^{2} \\
& +0.1882 \times 10^{-2}\left[\log _{10}\left(G^{\prime}\right)\right]^{3} .
\end{aligned}
$$

Figure 14 shows a comparison between the experimentally observed slopes of $R_{t} v s \lambda^{2}$ and those predicted theoretically. There is a good agreement between the two at higher growth speeds where the microstructure is dendritic. However, the agreement is poor at low growth speeds where the morphology is cellular. The difference between the experimental values and theoretical predictions shows a systematic increase with decreasing growth speed.

The analysis presented previously, however, assumes diffusive solutal and thermal transports. There is significant convection present during directional solidification of these alloys, as indicated by the presence of longitudinal macrosegregation (Figure 3). The extent of convection increases with decreasing growth speed because of the increasing extent of the density inversion ahead of the array tips. This convection may be responsible for the discrepancy between the experimentally observed and theoretically estimated slopes of $R_{t} v s \lambda^{2}$ plots, which also increases with decreasing growth speed.

\section{SUMMARY}

Directional solidification of $\mathrm{Pb}-5.8$ wt pet $\mathrm{Sb}$ alloy at a given thermal gradient and growth rate produces a range of tip radii and primary spacings for both the cellular and dendritic arrays. The cells and dendrites in an array do not have a uniform mushy zone length. Some of them lead their immediate neighbors, and some lag behind. This scatter in the morphology of the immediate neighbors within an array may be attributed to the natural convection during growth of this alloy caused by the density inversion in the interdendritic melt and in the bulk melt immediately ahead of the array. However, some scatter may be due to the natural competition among the neighbors, which would be present even under purely diffusive thermal and solutal mass transport conditions. Only low gravity experiments can resolve this dilemma. It is interesting, however, that despite the convection present during these experiments, the tip radii are approximately proportional to the square of the primary spacings, a behavior predicted by the dendrite models based on diffusive transport; and the experimentally observed cell/ dendrite tip radii are in a good agreement with the predictions from the model due to Hunt-Lu. ${ }^{[8]}$

\section{ACKNOWLEDGMENTS}

This research was supported by the Microgravity Materials Research Program at NASA-Marshall Space Flight Center (Huntsville, AL). Appreciation is expressed to Professors Rohit Trivedi and David Poirier for many helpful discussions.

\section{REFERENCES}

1. M.H. Burden and J.D. Hunt: J. Cryst. Growth, 1974, vol. 22, pp. 109-16.

2. R. Trivedi: J. Cryst. Growth, 1980, vol. 49, pp. 219-32.

3. V. Laxmanan: J. Cryst. Growth, 1987, vol. 83, pp. 573-90.

4. S.H. Hahn and R. Trivedi: Acta Metall. Mater., 1994, vol. 42, pp. 25-34.

5. S.N. Tewari and M.A. Chopra: Metall. Trans. A, 1991, vol. 22A, pp. 2467-74.

6. B. Billia, H. Jamgotchian, and H.N. Thi: Metall. Trans. A, 1991, vol. 22A, pp. 3041-50.

7. G.L. Ding, W.D. Huang, X.Huang, X. Lin, and Y.H. Zhou: Acta Mater, 1996, vol. 44 (9), pp. 3705-09.

8. J.D. Hunt and S.Z. Lu: Metall. Mater. Trans. A, 1996, vol. 27A, pp. 611-23.

9. J.A. Warren and J.S. Langer: Phys. Rev. E, 1993, vol. E47, pp. 2702-12.

10. B.J. Spencer and H.E. Huppert: Acta Mater, 1997, vol. 45 (4), pp. 1535-49.

11. M.H. Burden, D.J.H. Hebditch, and J.D. Hunt: J. Cryst. Growth, 1973, vol. 20, pp. 121-24.

12. Leica Ultramiller is a product of Leica Inc., Deerfield, IL.

13. IRIS Explorer is a product of The Numerical Algorithms Group Ltd., Chicago, IL.

14. S.N. Ojha, G. Ding, L. Yu, J. Reye, and S.N. Tewari: Metall. Mater. Trans. A, 1999, vol. 30A, pp. 2167-71.

15. Metals Handbook, 8th ed., ASM, Metals Park, OH, 1961, vol. 8, p. 329.

16. S.D.E. Cheveigne, C. Guthmann, and P. Kurowski: J. Cryst. Growth, 1988, vol. 92, pp. 616-28.

17. K. Niwa, M. Shimoji, S. Kado, Y. Watanabe, and T. Yokokawa: Trans. AIME, 1957, vol. 209, pp. 96-101.

18. J.D. Hunt: Solidification Processing and Casting of Metals, The Metals Society, London, 1979, Book 192, pp. 3-11.

19. R. Trivedi: Metall. Trans. A, 1984, vol. 15, pp. 977-82. 